\title{
Factors Affecting Student Performance in a Graduate Information Systems Course: An Empirical Study at a US Commuter Public University
}

\author{
Mostafa Maksy \\ Kutztown University of Pennsylvania \\ Myung-Ho Yoon \\ Northeastern Illinois University
}

\begin{abstract}
The grade student intends to earn, the student's prior Information Technology/Information Systems skill level and the student's written and oral communications skill level lend significant support to student performance in the Graduate Information Systems course. The number of work hours per week, work type, and course load per semester do not have any significant negative effect on student performance. The grades in Accounting for Managers course and overall GPA are strong predictors of student performance. There is weak to moderate evidence that older students perform better than younger students. Lastly, undergraduate major has a significant positive effect on student performance in the following order: Accounting, Finance, Business Administration, other non-business major, Management, and Marketing.
\end{abstract}

Keywords: supporting factors, distraction factors, prior ability factors, student performance, management information systems

\section{INTRODUCTION}

Past research studies have explored multiple factors (e.g., academic performance, aptitude, prior exposure to mathematics, prior exposure to accounting, age, gender, motivation, effort, computer games and applications, online homework management packages, and other intervening variables) that have been found to be associated with student performance in college-level courses. The current study investigates the associations between selected supporting, distracting, prior ability, and other factors, and student performance in a Graduate Information Systems (GIS) course at a Midwestern commuter public university in the United States.

The supporting factors selected include the grade the students intended to earn (IG) in the GIS course, Information Technology/Information Systems skill level (IT/IS), and oral and written Communications skill level (Comm.) As proxies for distracting factors, the authors used the number of work hours per week, the type of work (whether or not it is related to accounting, or business in general) and the number of courses taken for the semester. Students' prior abilities were measured by the actual grade earned in a prerequisite course, COBM 401 (Accounting for Managers) and Overall Grade Point Average (OGPA). COBM 401 is a graduate course that covers principles of financial and managerial accounting and is 
designed for students who have no prior knowledge of accounting. Other factors studied are age, gender, and the undergraduate major of the students. The dependent variable, student performance, was measured in two different ways as follows: the letter grade for the course (hereafter referred to as 'Grade'), and the total overall points percent score (hereafter referred to as 'Points') for the course.

One of the motivations of this study is predicated on the belief that identifying factors that support students to perform well and factors that distract them from performing well may help us emphasize the supporting factors and discourage the distracting factors.

The remaining parts of the paper present a review of prior research, study objectives and independent variables, dependent variables, hypotheses, research methodology, and results. The paper ends with conclusions and recommendations, study limitations, and suggestions for further research.

\section{REVIEW OF PRIOR RESEARCH}

Several studies have examined the association between various factors (e.g., general academic performance, aptitude, prior exposure to mathematics, prior exposure to accounting, motivation, effort, age, gender, and other intervening variables, including metacognition and active learning approaches) and student performance in college-level courses.

The OGPA has been used frequently as a proxy for prior academic performance and aptitude. An overwhelming majority of researchers, using data from various U.S. colleges, have found evidence supporting OGPA as a significant predictor of performance in accounting courses (Eckel \& Johnson, 1983; Hicks \& Richardson, 1984; Ingram \& Peterson, 1987; Eskew \& Faley, 1988; Doran et al., 1991; Maksy \& Zheng, 2008; Maksy, 2012, 2014, 2017; Maksy \& Wagaman, 2012, 2013, 2015; Alanzi, 2015; Maksy \& Rodriguez, 2017; and Maksy \& Yoon, 2019). In the finance discipline, researchers (Paulsen \& Gentry, 1995; Chan et al., 1997; Sen et al., 1997; Didia \& Hasnat, 1998; Marks, 1998; Van Ness et al., 2000; Johnson et al., 2002; Biktimirov \& Klassen, 2008, and Maksy \& Rezvanian, 2017) found OGPA as a strong predictor of grade performance in Financial Management courses required of all business majors. Gupta and Maksy (2014) found OGPA as a strong predictor of student performance in an Investments course, as well as Maksy and Rezvanian (2017) in an introductory finance course. Wooten (1998) found that aptitude, as measured by the Scholastic Aptitude Test (SAT) score and grade history were significant variables in influencing performance of students in an introductory accounting course. U.S. research findings are supported in Australia by Jackling and Anderson (1998) and in Scotland by Duff (2004). Some exceptions to these results include Gist et al. (1996) who, using a different measure (pre-university examination performance), found no significant association between academic performance and performance in accounting courses at the university level. Also, in Wales, Lane and Porch (2002) found that performance in introductory accounting can partially be explained by reference to factors in the students' pre-university background; however, the authors also found these factors as not significant as students progressed to upper level accounting courses.

Management Information Systems is a required course for the accounting major in most colleges, and often a required course for any business major, requiring basic information processing skills and basic quantitative skills. Tan \& Choo (1990) tested the relationship between students' information processing strategies and academic performance and showed that students who use deep-elaborative information processing outperformed students who used shallow-reiterative information processing in management accounting and information systems courses. Heales (2005) examined whether students who have had access to computer and prior knowledge in office productivity tools perform better than students who did not have such exposure. He found that there is significant relationship between student performance and proficiency in productivity tools and that the relationship between performance and prior access to computer was correlated but not significant. Ballou \& Huguenard (2008) reported that higher levels of perceived computer experience positively affected the performance in an introductory information systems course. Higher levels of positive class behaviors (attendance and extra-credit participation) also affected the student performance. 
Some of these basic skills are also acquired through high school and prerequisite college courses such as Financial Accounting. Several studies have investigated the impact of prior exposure to mathematics and accounting on performance in college accounting courses and the results are inconclusive. A number of studies (Baldwin \& Howe, 1982; Bergin, 1983; and Schroeder, 1986) found that performance was not significantly associated with prior exposure to high school accounting education, while other studies (Eskew \& Faley, 1988; Bartlett, et al., 1993; Gul \& Fong, 1993; Tho, 1994; and Rohde \& Kavanagh, 1996) found that prior accounting knowledge, obtained through high school education, was a significant determinant of performance in college-level accounting courses. In addition, there is ambiguity with regard to the influence of mathematical background on performance in accounting courses. For example, Eskew and Faley (1988), and Gul and Fong (1993) suggested that students with strong mathematical backgrounds outperform students with weaker mathematical backgrounds. Seow et al. (2014) reported that prior academic achievement, admission interview, critical thinking, and mathematical aptitude were significantly associated with successful academic performance in an undergraduate accounting degree at a Singapore University. Alanzi and Alfraih (2017) found that accumulated quantitative knowledge has positive impact on academic performance in Cost Accounting; however, Gist et al. (1996) did not report the same results. Furthermore, Guney (2009) suggested that grades in secondary education mathematics are a very strong determinant of performance in accounting but only for non-accounting majors.

The majority of researchers have observed strong associations between student performance in introductory accounting and their performance in non-introductory accounting courses, but there are some exceptions. For example, Canlar (1986) found evidence that college-level exposure to accounting is positively related to student performance in the first MBA-level financial accounting course. Additionally, Tickell and Smyrnios (2005) found that the best predictor of academic performance in any one year is the performance in the same discipline in the previous year. Maksy and Zheng (2008), Maksy and Wagaman (2012, 2013, 2015), and Maksy and Rodriguez (2017) found that OGPA and the grade in Intermediate accounting II are strong predictors of student performance in Advanced accounting, Auditing, and Senior seminar in accounting courses. Gupta and Maksy (2014) reported that OGPA and grades in Financial accounting and Managerial accounting courses were strong predictors of student performance in an Investments course. However, an exception to this was Doran et al. (1991) who reported surprising and counterintuitive results that performance in the Introductory accounting course has a negative impact on performance in subsequent accounting courses.

Most prior studies about the influence of motivation or the combination of motivation and effort on student performance show positive effect. For example, Pascarella and Terenzini (1991) reported that motivation and effort, among other factors, significantly influence students' performance in college. Paulsen and Gentry (1995) reported that students' academic performance in a large introductory Financial management course was significantly related to several motivational variables such as intrinsic and extrinsic goal orientations and task value, and learning strategy variables, including time, study, and effort. Wooten (1998) found that motivation significantly affects effort, which in turn significantly affects performance in an introductory accounting course. Lane and Porch (2002) suggested that other important factors like student motivation may explain student performance. Several studies involving different accounting courses have used the 'grade student intends to earn in the course' as a proxy for motivation, showing a consistent pattern of positive association with student performance. Some of these accounting studies involved participants taking Advanced accounting (Maksy \& Zheng, 2008; Maksy \& Wagaman, 2015; Maksy, 2017), Intermediate accounting (Maksy, 2012, 2014), Auditing (Maksy \& Zheng, 2008; Maksy \& Wagaman, 2012; Maksy \& Rodriguez, 2017), Cost Accounting II (Maksy \& Yoon, 2019) and Senior seminar in accounting (Maksy \& Wagaman, 2013). Finance courses with students taking Introduction to finance (Maksy \& Rezvanian, 2017), and Investments (Gupta \& Maksy, 2014) have shown similar results.

Chan et al. (2016) developed an educational computer program to enhance intrinsic motivation and performance in accounting courses. Their results showed higher intrinsic motivation than with the use of Blackboard and other traditional paper forms. Brown et al. (2016) aimed to assess student perceptions on the implementation of guided reading questions to motivate and enhance student reading and adequate 
participation in class discussions or other course areas. They found that student perception results demonstrated that the guided reading questions had a positive impact on student motivation, reading comprehension, effort level, and understanding of the material before attending class. Poh-Sun, and SuayPeng (2016) used a mobile gaming app called Accounting Challenge (ACE) for learning accounting in a fun way, indicating that ACE won three international teaching awards. The ACE tool is free and allows students to learn accounting outside a classroom setting. The authors reported that the app received favorable reviews by users, and added that although the app was downloaded 23,230 times with users in 90 countries at the time of their study, further investigations seem appropriate to identify and substantiate its academic benefits. Everaert et al. (2017) used first-year undergraduates to explore deep learning and surface learning (precedents and consequences of learning approaches, respectively) with motivation as precedent, and time spent and academic performance as consequences. They reported that accounting students showed a higher score for deep learning over surface learning that lead to higher academic performance. The results also indicated a positive association between high intrinsic motivation and extrinsic motivation, and deep learning.

Prior studies about the effect of effort per se on student performance show conflicting results. For example, using self-reported data, Didia and Hasnat (1998) presented rather weak counter-intuitive evidence (for one of the two OLS models, but not for the ordered-probit models) that the more time spent studying per week the lower the grade in the introductory finance course; however, they did not control for OGPA. Using self-reported data, Nofsinger and Petry (1999) found no significant association between effort and performance in a Principles of Finance course. Also, Biktimirov and Klassen (2008) found weak association between hits to course management system and grade in a finance course. In contrast, Johnson et al. (2002) utilize computerized quizzes and analyzed the effect of objectively measured effort on student performance in a Financial Management course. These authors showed that, after controlling for aptitude, ability, and gender, effort (as measured by attempts and log time) remains significant in explaining the differences in performance. In addition, Rich (2006) used students' homework preparedness and unpreparedness in class as a proxy for effort and non-effort. He found significant positive association for the former and negative association for the latter with exam percent. More recently, Gupta and Maksy (2014) studied the effect of several effort factors (number of course study hours, overall study hours, homework score, class attendance, and class participation) on student performance in an Investments course. They found the number of course study hours, homework score, and class attendance to have varied levels of significance (in some cases lack thereof) depending upon how student performance was measured under ANOVA, Pearson and Spearman correlations, and OLS regression - including controlling for certain variables as part of the analysis.

Several prior studies also investigated various factors that distract students and cause them to have low performance or withdraw from college altogether. The results of some of these studies are expected but the results of some other studies are not. For example, in the accounting area, Paisey and Paisey (2004), and Guney (2009) demonstrated that there is a clear positive association between attendance and academic performance in accounting courses. Paisey and Paisey (2004) also reported that the most frequently cited reason for not attending classes was students' participation in part-time employment. Lynn and Robinson-Backmon (2005) found a significant adverse association between employment status and learning outcomes in upper-division accounting courses. Tessema et al. (2014) reported that students who work 10 hours or less per week are more satisfied and have higher OGPAs than students who work more than 10 hours per week. Alanzi (2015) found significant association between class attendance, college experience, and student performance in a Cost Accounting course at a university in Kuwait. Fortin et al. (2016) investigated the reasons nontraditional students in several universities in Quebec, Canada, withdrew from undergraduate accounting programs. As expected, they found that the reasons include the following: returning to school after working for some time, enrollment in a non-first choice programs, dissatisfaction with program choice and courses, and low OGPA, the latter being the main reason for student withdrawal. Other factors found to influence withdrawal decisions were related to time management, and family responsibilities, especially for women. The authors suggested that students could benefit from university support that would enhance their learning strategies and improve student 
performance. Pavione et al. (2016) identified a number of factors influencing the process of teaching and learning according to accounting students in the state of Minas Gerais, Brazil. Those factors were teacher's didactics (how the teacher leads the class, interacts with students and provides for a learning environment), content structure of the course, desire to learn the subject (personal motivation), and library resources (institution support). The four highest scores related to low student performance were lack of interest, and lack of dedication outside the classroom (students), and does not intend to address the concerns of students, and not mastering the subject matter to be explained (instructors).

Chan, et al. (1997), on the other hand, found no significant association between performance in a Financial Management course, attendance, credit hours enrolled, and number of weekly work hours. Didia and Hasnat (1998) found strong positive association between number of credit hours enrolled in the semester and course grades. Wooten (1998) found no significant association between work, family, and extra-curricular conflicts and students' performance in an introduction to accounting course. Van Ness et al. (2000) found no association between students' full-time or part-time status and grades in a Principles of Finance class. However, the authors found that students who are enrolled in an online class are more likely not to complete the course. This appears to be counter-intuitive because the Internet course is designed to give students more control over their learning in terms of very flexible deadline for assignments and one full year to complete the course. Rich (2006) reported significant negative association between class absences and being late to the class, and exam percent. Maksy and Zheng (2008), Maksy (2012, 2014, 2017), Gupta and Maksy (2014), Maksy and Wagaman (2012, 2013, 2015), Maksy \& Rezvanian (2017), Maksy \& Rodriguez (2017), and Maksy \& Yoon (2019) found no significant negative association between the number of hours of work per week and student performance in several accounting, auditing, finance, and investment courses.

Age and gender are two demographic variables that received less attention than those factors discussed above, but most of the studies related to age and gender produced conflicting results. Some studies showed that younger students performed better than older ones but other studies showed opposite results. Also, some studies indicated that female students perform better than male students but other studies showed opposite results. For example, in the field of accounting, Bartlett et al. (1993) and Kohl and Kohl (1999) suggested that younger students have better performance, particularly at the senior university level. However, Schrouder and Rhodd (2013) reported that older and more experienced students perform better than younger and less experienced students in a Public Administration course. With respect to gender, Mutchler et al. (1987) found that female students score significantly higher than male students. Gracia and Jenkins (2003) pointed out a significant difference in favor of the performance of female students over male students in Wales. Almunals et al. (2014) reported that females perform better than males in the accounting major. They also found other factors significantly associated with the performance of students majoring in accounting, including high school major (science majors perform better than humanities majors), marital status (married students perform better than single students), frequency of doing homework, class participation, peer interaction, and number of days studying before the exam (the higher the frequency the higher the performance). However, some studies indicated that male students perform better than female students, but the results are either insignificant (Lipe, 1989) or only hold true for introductory courses (Doran et al., 1991). Sen et al. (1997) showed that female students performed worse than male students in Principles of finance courses at two different mid-western U.S. universities. Garas and Hassan (2018) examined how technology-based assessment is affected by the gender in an introductory financial accounting course and found that males performed better than females on computer-based test and that females outperformed on paper-based test.

Most studies have shown that the age and gender of students have no effect on students' performance. For example, Chan et al. (1997), Didia and Hasnat (1998), and Van Ness et al. (2000) found no significant association between grade in an introductory finance course and gender or age of students. Alanzi (2015) found that gender, age, nationality, scores and majors in high school, grades in prerequisite courses, and OGPA in college have no significant association with student performance in Cost Accounting. Jenkins (1998), and Lane and Porch (2002) concluded that age is not a significant determinant of performance in Auditing and Management accounting courses. Tyson (1989) and Buckless 
et al. (1991) demonstrated that gender effect disappears after controlling for general academic ability. Henebry and Diamond (1998) and Johnson et al. (2002) also did not find any significant association between a finance principles course score and gender. However, Henebry and Diamond (1998) showed that students earn significantly higher grades in courses taught by female instructors. This difference was not attributable to adjunct, tenure track, or tenured status of instructors. Gammie et al. (2003) found very little indication of performance differential between males and females throughout the degree program.

There has also been increased interest in studying the influence of intervening variables on student performance. Bartlett et al. (1993) concluded that very few of the educational, demographic or financial characteristics variables appear to have a significant influence on student performance in university accounting examinations. In recent years, several studies have shown that metacognition attributes have positive effects on student performance. Metacognition is frequently described as 'thinking about thinking' and includes knowledge about when and how to use particular strategies for learning or for problem solving. Paulsen and Gentry (1995) found that academic performance in a large introductory financial management class was significantly related to control over learning, test anxiety, self-efficacy, elaboration, organization and metacognition. Gracia and Jenkins (2003) observed that students who demonstrated commitment and self-responsibility towards their studies tended to do well in formal assessments. Lynn and Robinson-Backmon (2005) indicated that a student's self-assessment of course learning objectives is significantly related to grade performance. Schleifer and Dull (2009) addressed metacognition in students and found a strong link between metacognitive attributes and academic performance. Lin and Songtao (2016) examined the impact of metacognitive awareness (measured by Learning Smart, an online learning tool supplemented with the textbook) on class performance in financial accounting courses and found that students with greater metacognitive awareness performed better. Tepper and Yourstone (2018) investigated the effect of self-efficacy as a non-cognitive predictor of student success in an introductory accounting class. Their results showed that students with similar ACT and GPA outperformed others owing to non-cognitive variables pertaining to self-efficacy, such as individual's perceived skill level and expected performance.

Several prior studies also investigated the effect of active learning versus passive learning approaches on student performance with the majority showing that active learning approaches have much more positive effect on student performance than passive learning. For example, Andres (2017) examined active learning using Kolb's experiential learning, Pintrich's student learning motivation, and cognitive load theories and found that active learning was a positive predictor of course grade, reducing the negative relationship between course difficulty on learning motivation and course grade. Dutra de Oliveira Neto et al. (2017) investigated the performance of students from a public university in Brazil that used the flipped classroom and found that it improved student performance and that students approved of it as an appropriate teaching strategy. Riley and Ward (2017) examined the effectiveness of active learning, cooperative active learning, and passive learning methods in an Accounting Information Systems course. Their results indicated that active learning enhance student performance, especially for those students who work individually. Wynn-Williams et al. (2016) examined deep and surface approaches to learning in a university Intermediate-level accounting class that used business cases in the group presentations. Their results supported the claim that students focus on what is required; hence, concluding that if deeper approaches to learning are desirable, assessments would likely need to reward such behavior. Fadol et al. (2018) examined the impact of three delivery modes (traditional, online, and flipped) on student performance in a management course in the Middle East. They found that both the online and flipped sections performed better than the traditional one and that flipped section performed better than the online one. Accessing online materials improved the performance in the online and flipped sections. Trout (2018) examined the effect of class format on student performance in the first accounting course. He found that students in the one-day-a week class showed higher grades than in the two-days-aweek class and spent more time on online homework since they might be better motivated to attend each class session.

While prior research has been largely inconclusive or replete with conflicting results, it is not the purpose of this study to resolve all those conflicts. The authors' objective in the current study is to 
provide additional insight on those areas in which there have been some general consensus. Since motivation and effort usually have been positively associated with student performance, the authors aimed to test whether some new selected motivating and supporting factors affect student performance in the Graduate Information Systems (GIS) course. The current study also looked at several factors which are commonly viewed as possibly distracting students from performing well and tested whether they indeed are negatively affecting student performance. Furthermore, the current study investigated the impact of three specific measures of prior abilities on student performance and used them as control variables while testing for the association between supporting and distracting factors and student performance in the GIS course.

\section{STUDY OBJECTIVES AND INDEPENDENT VARIABLES}

The first objective of this study is to examine the association between three selected factors that lend support to the students to earn higher grades in the GIS course (the grade the student intends to earn in the course, the student's prior level of Information Technology/Information Systems skill level and the student's oral and written communications skill level), and the student's performance in the GIS course at a Midwestern commuter public university in the United States. The authors hypothesize that there are positive and significant associations between those supporting factors and student performance. Students who intend to earn higher grades are self-motivated to study hard to achieve their intention. Also, students whose prior IT/IS skill level is high will do better in the GIS course than students whose prior IT/IS skill level is low because the course requires the knowledge of computer hardware, software, application systems, and the use of several productivity programs (e.g., spreadsheet, database, etc.). Likewise, students whose oral and written communications skill level is very good will do better in the GIS course than students whose oral and written communications skill level is not so good because the course also requires several written and oral presentations assignments.

The second objective is to examine the association between three distracting factors (the student's number of work hours per week during the semester, the student's work type - whether or not it is related to IT/IS, accounting, or business in general - and the student's number of courses taken in the semester) and the student's performance in the GIS course. Intuitively, the higher the number of work hours per week, the less time the student will have to study for the course resulting in lower course grade. Furthermore, if the student's work is not related to IT/IS, accounting, or business in general, the student's grade in the GIS course will be lower than if the student's work is related to one of these areas in that order. Additionally, it is likely that the performance of a student taking higher number of courses will be affected negatively because the student may not be able to devote sufficient number of hours of study to the course. In light of the above discussion, the authors hypothesize that if the student's number of work hours per week is high, and/or the student's work is not related to IT/IS, accounting, or business in general, and/or the number of courses taken in the semester is higher than average, there will be a significant negative association between these distracting factors and the student's performance in the GIS course. The potential exists for distracting factors to offset each other, thereby cancelling out any single factor effect. For example, a student who works higher number of hours per week may take fewer courses, and vice versa, so that there is no negative effect on performance. For this reason, the authors tested the effect of each distracting factor on student performance while controlling for the other two factors. The authors also tested the effect of each distracting factor on student performance while controlling for the other two factors as well as the prior ability factors (COBM 401 grade and OGPA).

The third objective is to examine the association between students' performance in the GIS course and their grade in the pre-requisite COBM 401(Accounting for Managers) course, and their overall GPA (OGPA). Based on the results of several prior studies, the authors hypothesize that there are positive and significant associations between these prior actual abilities factors and student performance. Thus, the hypotheses are that students who earned higher grades in Accounting for Managers, or have high OGPAs, will earn higher grades in the GIS course, and vice versa. 
The fourth objective is to examine the association between students' performance in the GIS course and some other factors (specifically, age, gender, and undergraduate major). Based on the results of most prior studies, the authors do not expect any significant association between age or gender and student performance in the GIS course. The authors included these two variables to empirically show that the results of this study are in line with the results of most prior studies. The authors believe that the undergraduate major will have a significant effect on student performance because students whose undergraduate major is accounting are expected to have better performance in the GIS course (which is an accounting course) than students whose undergraduate major is finance, management, marketing, or business in general.

\section{STUDY DEPENDENT VARIABLES}

In addition to 11 independent variables described above, the study uses two dependent variables. The authors initially used the letter grade in the course (A, B, C. etc.) as the student performance dependent variable. However, the letter grade treats a student earning the lowest end of the grade range as having the same exact performance as that of a student earning the highest end of the grade range. For example, a student with a total percentage points of 80 and another with a total percentage points of 89 would be considered having equal performance since both students receive a B for the course, even though the first student is one percentage point away from a $\mathrm{C}$ grade and the other student is one percentage point away from an A grade. As a result, the authors also decided to use overall points percentage earned by a student in the course as a dependent variable.

\section{STUDY HYPOTHESES}

The study tests one hypothesis for each independent variable. The formal statements of all 11 hypotheses are presented (classified under four categories of factors) as follow. To prevent redundancy, each hypothesis is presented in the alternate form only.

\section{Supporting Factors}

$\boldsymbol{H}_{1}$ : There is a significant positive association between the grade the student intends to earn in the GIS course and student performance in that course.

$\boldsymbol{H}_{2}$ : There is a significant positive association between the student's IT/IS skill level and student performance in the GIS course.

$\boldsymbol{H}_{3}$ : There is a significant positive association between the student's oral and written communication level and student performance in the GIS course.

\section{Distracting Factors}

$\boldsymbol{H}_{4}$ : There is a significant negative association between the student's average number of work hours per week and student performance in the GIS course.

$\boldsymbol{H}_{5}$ : There is a significant negative association between the student's work type (if it is not related IT, accounting, or business in general) and student performance in the GIS course.

$\boldsymbol{H}_{6}:$ There is a significant negative association between the number of semester courses a student is taking and that student's performance in the GIS course.

\section{Prior Ability Factors}

$\boldsymbol{H}_{7}:$ There is a significant positive association between the grade the student earned in the Accounting for Managers graduate course and student performance in the GIS course.

$\boldsymbol{H}_{8}$ : There is a significant positive association between the student's OGPA and student performance in the GIS course. 


\section{Other Factors}

$\boldsymbol{H}_{9:}$ There is no significant association between the student's age and student performance in the GIS course.

$\boldsymbol{H}_{10}$ : There is no significant association between the student's gender and student performance in the GIS course.

$\boldsymbol{H}_{11}$ : There is a significant association between the student's undergraduate major and student performance in the GIS course.

\section{RESEARCH METHODOLOGY}

\section{Survey Instrument:}

The authors modified a list of survey questions, from Ingram et al. (2002) to include, besides the study variables, some demographic and other information.

\section{Study Sample:}

The authors were able to collect usable data on the survey instrument from 129 students enrolled in five sections of the GIS course offered over several semesters ending in spring 2019 at a major public commuter university in Chicago. All sections were taught by the same instructor using the same textbook. So, instructor's and textbook's effects on the results are not a problem. The study school serves nearly 9,000 students $-7,300$ undergraduates, and 1,700 graduates. The College of Business and Management enrolls approximately 1,600 students.

The authors coded and entered the data on two different Excel spreadsheets which were later matched and actions taken to solve any discrepancies. This process virtually eliminated any possible data entry errors.

\section{Data Analysis:}

To test the formulated hypotheses, the authors used a one-way analysis of variance (ANOVA), Pearson and Spearman correlation coefficients, partial correlations, and ordinary least square (OLS) linear regressions.

\section{STUDY RESULTS}

Table 1 presents descriptive statistics (e.g., minimum and maximum value, mean, and standard deviation) for each of the 13 variables of the study. Table 1 shows an average grade in the GIS course of 3.65 which is somewhat higher than the average grade of 3.53 in the prerequisite Accounting for Managers course. It is also higher than the OGPA of 3.57, but it is lower than the average Intended Grade of 3.93. This indicates that while the students performed better than their prior abilities they were over optimistic about the grade they intended to earn in the GIS course.

The following is an analysis of the study results by the type of factors investigated (supporting, distracting, prior abilities, and other) taking all observations into account.

\section{Supporting Factors Affecting Student Performance}

As Tables 2 and 3 indicate, all three supporting factors, IG, IT/IS and Communication, are significantly associated (at the .01 level of significance) with student performance (however defined) based on ANOVA and Pearson/Spearman correlations tests, except for Communication with "Grade" at the .05 level. However, as Table 5 indicates, only IG and Communication are significantly associated (at the .01 level) with student performance. Furthermore, as Table 4 indicates, when the authors controlled for the prior ability factors (COBM 401 grade and OGPA) all the significant associations between three supporting factors and student performance shown under Pearson and Spearman correlations remained significant at the .01 level.

In light of the above analysis the authors can generally state that $\mathrm{H}_{1}, \mathrm{H}_{2}$, and $\mathrm{H}_{3}$ have been supported. 


\section{Distracting Factors Affecting Student Performance}

As Tables 2, 3, and 5 indicate, none of the three distracting factors discussed in $\mathrm{H}_{4}$ to $\mathrm{H}_{6}$ has any significant negative association with student performance (however defined) under the ANOVA, Pearson/Spearman correlations, and the regression tests. However, the ANOVA test shows a significant (and presumably positive) association (at the .10 level of significance) between Work Type and student performance, however defined. Also, Pearson and Spearman correlation tests show significant positive associations (mostly at the .05 level of significance) between Work Type and student performance, however defined. However, after the authors controlled for the prior ability factors (the grade in COBM 401 and OGPA), as shown in TABLE 4, these positive association between work type and student performance totally disappeared. This means that if we take students who had the same grade in COBM 401 and about the same OGPA, we find no significance difference between the performance of these students in the GIS course regardless of their work type.

Nevertheless, when the authors controlled for the other two distraction factors (Work Hours and Course Load), as shown in Table 6, Panel A, the significance level of the positive associations between work type and student performance not only remained significant but the significance level improved somewhat. But again, when the authors controlled for the other two distraction factors as well as prior ability factors, as shown in Table 6, Panel B, these positive associations totally disappeared. This confirms, once more, that the prior ability factors, not the work type, are driving the performance in the GIS course. Furthermore, the regression test, in Table 5, does not show any significant positive association between work type and student performance. Nevertheless, because the ANOVA and Pearson/Spearman correlations tests show positive associations between work type and student performance, and because the significance of these associations strengthened somewhat after controlling for work hours and course load, a question arises: which work type has positive effect on student performance? In an effort to find the answer to this question, the authors ran cross tabulation of work type and grade and the results are shown in Table 7. As Table 7 indicates, and as would be expected, students whose jobs are IT/IS related performed significantly better than students whose jobs are accounting related. Students whose jobs are IT/IS related, while their number is small (only 11 out of 129 , or $9 \%$ of the sample) all of them earned an A for the course. On the other hand, of the 30 students (representing $23 \%$ of the sample) whose jobs are accounting related, 24 (or $80 \%$ ) earned A, 5 (or $28 \%$ ) earned a B, and the remaining one (or 3\%) earned a C. Contrasting these statistics with those of the 76 students (or 59\% of the sample) whose jobs are business (but not IT/IS or accounting related), we find that only $64 \%$ of them earned an A, 28\% earned a B, 7\% percent earned a C, and one student got a D. Two-thirds of the 12 students (or $9 \%$ of the sample) who do not work earned an A and one-third earned a B. So, even this latter group of students performed relatively better than students whose jobs are business (but not IT/IS or accounting) related.

In light of the above analysis the authors can generally state that none of the three hypotheses $\mathrm{H}_{4}$ to $\mathrm{H}_{6}$ was supported.

The results observed in this study, indicating no significant negative association between Work Hours, Work Type, and Course Load and student performance, after controlling for the other two distracting factors, whether or not prior abilities are controlled for, are in agreement with some prior studies (Maksy \& Zheng, 2008; Gupta \& Maksy, 2014; Maksy, 2012, 2017; Maksy \& Rezvanian, 2017; Maksy \& Rodriguez, 2017; and Maksy \& Yoon, 2019).

\section{Prior Actual Ability (Control) Factors Affecting Student Performance}

The ANOVA test (Table 2) and Pearson/Spearman correlation tests (Table 3) show significant associations (at the .01 level) between each of the two prior ability factors (COBM 401 grade and OGPA) and student performance, however defined. The regression test (Table 5) shows similar association but at lower significance levels depending on the definition of student performance. It shows that COBM 401 grade is associated with student performance but only when it is defined as "Grade" and only at the .10 significance level. It also shows that OGPA is associated with student performance but only when it is defined as "Points" and only at the .05 significance level. 
The strong significant associations between OGPA and student performance in this study, are consistent with the results reported by Maksy and Zheng (2008), Maksy (2012), Gupta and Maksy (2014), Maksy and Rodriguez (2017), Maksy and Rezvanian (2017), and Maksy and Yoon (2019).

\section{Other Factors (Age, Gender, and Undergraduate Major) Affecting Student Performance Age and Student Performance}

The ANOVA test (in Table 2) and Pearson/Spearman correlation tests (in Table 3) show significant associations (at the .05 level) between student age and student performance. The only exception to that statement is that, when performance is measured as Points, the association is weakened to a significance level of .10 under the ANOVA test. Furthermore, when the authors controlled for the prior ability factors, as Table 4 indicates, the significant association between age and student performance totally disappeared when performance is defined as "Points" and the significance level is weakened to .10 when performance is defined as "Grade." The regression test (Table 5) does not show any significant association between age and student performance when performance is defined as "Points" but shows a weak association (at the .10 level of significance) when performance is defined as "Grade."

While the results shown in Tables 2 and 3 indicate that older students (students aged 26+) perform significantly better than younger students (aged 20-25) in the GIS course, the fact that these differences disappear (when student performance is defined as Points) or their significance is weakened to the .10 level (when performance is defined as Grade) after the prior ability factors are controlled for, tells us that the prior abilities are driving the grades in the GIS course. In other words, when we take all students who have the same grades in COBM 401 and about the same OGPA, we find that the average points score of younger students is not significantly lower than the average points score of the older students, even though the average grade of younger students is significantly lower (but at the lowest significance level of .10) than the average grade of older students. Since the authors' hypothesis was that there is no significant difference in the performance of younger and older students, the research results lend little partial support to $\mathrm{H}_{10}$. This is so because we cannot ignore the results of the ANOVA and regression tests showing significant difference in performance between older and younger students, particularly when performance is measured as "Grade.". Also, Table 8 presents a cross tabulation of age and grade and it indicates that of the 109 students ( $85 \%$ of the sample) whose age is $26+$ years, 82 students (or $75 \%$ ) earned the grade of A, 22 (or 20\%) earned a B, and the remaining five (or 5\%) got a C. On the other hand, of the 20 students ( $15 \%$ of the sample) whose age is under 26 years, only 10 students (or 50\%) earned the grade of A, 8 (or $40 \%$ ) earned a B, one earned a C, and one earned a D. These appear to be significant differences; however, we must keep in mind that the older students' sample is much larger than (almost 5.5 times) the younger students' sample.

\section{Gender and Student Performance}

None of the tests in Tables 2, 3 and 5 show any significant association between gender and student performance, however defined. This lends support to $\mathrm{H}_{11}$. Interestingly, however, when the authors controlled for the prior ability factors, as indicated in Table 4, female students had significantly better performance (at the .05 level) when it is defined as 'Points." This means, of the students who have the same grade in COBM 401 and about the same OGPA, female students' average points in the GIS course is significantly higher than the average points of the male students. Furthermore, a cross tabulation of Grade and Gender in Table 9 shows that the grades of female students are quite higher than the grades of male students. Of the 69 female students, 52 (or 76\%) earned the grade of A, 15 (or 22\%) earned a B, one (or 1\%) earned a $\mathrm{C}$, and one earned a $\mathrm{D}$. On the other hand, of the 60 male students, only 40 (or $67 \%$ ) earned the grade of A, 15 (or 25\%) earned a B, and the remaining five (or $8 \%$ ) earned a C.

\section{Undergraduate Major and Student Performance}

The ANOVA test (in Table 2), Pearson/Spearman correlation tests (in Table 3), and the regression test (in Table 5) show significant associations between the student's undergraduate major and student performance (especially when it is defined as "Points") in the GIS course. When performance is measured 
as "Points", all three tests show that association to be significant at the .01 level. When performance is measured as "Grade" the ANOVA test shows the association to be significant at the .10 level, the Spearman correlations and the regression test show the association to be significant at the .05 level, but the Pearson correlations still show the association to be significant at the .01 level. When the authors controlled for prior ability factors (as shown in Table 4), the significant association was weakened to the .10 level of significance when performance is measured as "Grade" but remained significant at the .01 level when performance is measured as "Points." To identify which major (accounting, finance, management, marketing, business administration, or other non-business major) leads to better performance in the GIS course, the authors ran a cross-tabulation between undergraduate major and grade as shown in Table 10. Based on the percentages of grades earned (shown in parentheses in Table 10), for each undergraduate major sample, we find that the order of the undergraduate majors leading to better performance in the GIS course is as follows: accounting, finance, business administration, other nonbusiness major, management, and marketing. That is, students whose undergraduate major was accounting perform significantly better in the GIS course than students whose undergraduate major was finance and the latter perform significantly better than those whose undergraduate major was business administration, and so on. Since the authors' hypothesis was that the undergraduate major will have a significant effect on student performance, the research results lend support to $\mathrm{H}_{11}$

\section{CONCLUSIONS AND RECOMMENDATIONS}

One general conclusion of the study is that motivated students (exhibited by their intention to earn higher grades) perform significantly better in the GIS course than non-motivated students.

In light of the above general conclusion, the authors recommend that GIS faculty should encourage their students to plan to earn higher grades and make effort to achieve their plans.

Another conclusion of the study is that the prior IT/IS skill level supports student performance in the GIS course; the higher the prior IT/IS skill level the higher the performance in the GIS course.

In light of the above general conclusion, the authors recommend that faculty should encourage their students to increase their information technology and information systems skills by any means available to them.

Another conclusion of the study is that oral and written communications skill level lends significant support to student performance in the GIS course.

In light of the above general conclusion, the authors argue that faculty teaching GIS courses should encourage their students at the beginning of semester to improve their oral and written communication skills by any means available at the university, for example, by going to the writing lab to get help in written communication. To improve their oral communication, students should try to present their research or projects at the student research and creative activities conferences that are conducted at most universities, counties, or regions.

Another general conclusion from the statistical tests of this study is that the distracting variables used in the study (i.e., number of work hours per week, working in non-accounting, or non-business-related jobs, and number of courses taken in the semester) have no significant negative associations with student performance.

In light of the above general conclusion, the authors recommend that faculty need not encourage their students to work as fewer hours per week as possible to earn high grades in the GIS course. Furthermore, if students have to work a significant number of hours anyway to support their families, faculty need not stress to the students that they must work in accounting-related or business-related jobs unless they have opportunities to work in accounting or business-related jobs. In addition, faculty need not encourage those students to take as fewer courses per semester as possible to earn high grades in the GIS course. Faculty may advise their students who plan to take higher than average course loads to make sure that they manage their time effectively. Finally, faculty, when advising students with poor performance, need to think of causes (e.g., poor study habits, poor time management, etc.) other than too many working hours 
per week, or jobs that are non-accounting or non-business related, or too many courses taken per semester, to pinpoint to those students.

As expected, and as shown in prior studies with respect to other courses, another general conclusion of the study is that students with high prior actual ability end up earning high grades in the GIS course. Specifically, the study provides evidence that there is a strong significant association between students' grades in the Accounting for Managers course (COBM 401) and OGPA and their performance in the GIS course.

In light of this general conclusion, the authors recommend that faculty encourage their students to study hard to earn high grades in all courses (including COBM 401) to improve their GPA by emphasizing that research shows that students with high OGPA tend to earn high grades in the GIS course. The authors recognize that many faculty members may already be encouraging their students to do just that; thus, these recommendations are primarily for faculty members who may not be encouraging their students in that regard.

\section{STUDY LIMITATIONS AND SUGGESTIONS FOR FURTHER RESEARCH}

Like most studies, this study is subject to some limitations. One such limitation pertains to the subjectivity embedded in the self-reported factors (e.g., Intended grade, prior IT/IS Skill level, and communications skill level) which are exposed to possible students' bias. Another limitation of this study is that the school is a public (state-supported) university; therefore, conclusions reached may not be applicable to private schools. A suggestion in this area is to replicate the study at a private college or university in order to compare and to contrast the results, and thus, to add to the literature. A third limitation is that the study school is a commuter university and, therefore, conclusions reached may not be applicable to residential schools. A recommendation for future research is to replicate the study at a residential college or university to determine whether the results will be the same or will be different.

\section{REFERENCES}

Alanzi, K. A. (2015). Determinants of students' performance in cost accounting - Further evidence from Kuwait. World Journal of Management, 6(1), 136-152.

Alanzi, K. A., \& Alfraih, M. (2017). Does accumulated knowledge impact academic performance in cost accounting? Journal of International Education in Business, 10(1), 2-11.

Almunals, T., Alfraih, M., \& Alharbi, F. (2014). Determinants of accounting students' performance. Business Education and Accreditation, 6(2), 1-9.

Andres, H. (2017). Active teaching as a moderator of course difficulty. Proceedings for the Northeast Region Decision Sciences Institute, 270-291.

Baldwin, B. A., \& Howe, K. R, (1982). Secondary-level study of accounting and subsequent performance in the first college course. The Accounting Review, 3, 619-626.

Ballou, D., \& Huguenard, B. (2008). The impact of students' perceived computer experience on behavior and performance in an introductory information systems course. Journal of Information Systems Education, 19(1), 87-97.

Bartlett, S. M., Peel. J., \& Pendlebury, M. (1993). From fresher to finalist: A three-year study of student performance on an accounting degree program. Accounting Education: An International Journal, $2,111-122$.

Bergin, L. J. (1983). The effect of previous accounting study on student performance in the first collegelevel financial accounting course. Issues in Accounting Education, 1, 19-28.

Biktimirov, E. N., \& Klassen, K. J. (2008, January/February). Association between use of online support materials and student performance in an introductory finance course. Journal of Education for Business, 153-158.

Brown, C. A., Danvers, K., \& Doran, D. T. (2016). Student perceptions on using guided reading questions to motivate student reading in the flipped classroom. Accounting Education, 25(3), 256-271. 
Buckless, F. A., Lipe, M. G., \& Ravenscroft, S.P. (1991). Do gender effects on accounting course performance persist after controlling for general academic aptitude? Issues in Accounting Education, 6, 248-261.

Canlar, M. (1986). College-level exposure to accounting study and its effect on student performance in the first MBA-level financial accounting course. Issues in Accounting Education, 1, 13-23.

Chan, K. C., Shum, C., \& Wright, D. J. (1997). Class attendance and student performance in principles of finance. Financial Practice and Education, 7(2), 58-65.

Chan, S. H., Song, Q., Rivera, L. H., \& Trongmateerut, P. (2016). Using an educational computer program to enhance student performance in financial accounting. Journal of Accounting Education, 36, 43-64.

Didia, D., \& Hasnat, B. (1998). The determinants of performance in the university introductory finance course. Financial Practice and Education, 1(1), 102-107.

Doran, B., Bouillon, M. L., \& Smith, C. G. (1991). Determinants of student performance in accounting principles I and II. Issues in Accounting Education, 6(1), 74-84.

Duff, A. (2004). Understanding academic performance and progression of first-year accounting and business economics undergraduates: The role of approaches to learning and prior academic achievement. Accounting Education, 13, 409-430.

Dutra de Oliveira Neto, J., de Sousa Gomes, G., \& Titton, L. A. (2017). Using technology driven flipped class to promote active learning in accounting. Revista Universo Contábil, 13(1), 49-64.

Eckel, N., \& Johnson, W. A. (1983). A model for screening and classifying potential. Accounting Education, 2, 1-15.

Eskew, R. K., \& Faley, R. H. (1988, January). Some determinants of student performance in the first college-level financial accounting course. The Accounting Review, 137-147.

Everaert, P., Opdecam, E., \& Maussen, S. (2017). The relationship between motivation, learning approaches, academic performance and time spent. Accounting Education, 26(1), 78-107.

Fadol, Y., Aldamen, H., \& Saadullah, S. (2018). A comparative analysis of flipped, online and traditional teaching: A case of female Middle Eastern management students. International Journal of Management Education, 16(2), 266-280.

Fortin, A., Sauvé, L., Viger, C., \& Landry, F. (2016). Nontraditional student withdrawal from undergraduate accounting programmes: A holistic perspective. Accounting Education, 25(5), 437478.

Gammie, E., Paver, B., Gammie, B., \& Duncan, F. (2003). Gender differences in accounting education: An undergraduate exploration. Accounting Education, 12, 177-197.

Garas, S., \& Hassan, M. (2018). Student performance on computer-based tests versus paper-based test in introductory financial accounting: UAE evidence. Academy of Accounting \& Financial Studies Journal, 22(2), 1-14.

Gist, W. E., Goedde, H., \& Ward, B. H. (1996). The influence of mathematical skills and other factors on minority student performance in principles of accounting. Issues in Accounting Education, 1, 4960 .

Gracia, L., \& Jenkins, E. (2003). A quantitative exploration on an undergraduate accounting programme of study. Accounting Education, 12, 15-32.

Gul, F. A., \& Fong. S. C. (1993). Predicting success for introductory accounting students: Some further Hong Kong evidence. Accounting Education: An international journal, 1, 33-42.

Guney, Y. (2009). Exogenous and endogenous factors influencing students' performance in undergraduate accounting modules. Accounting Education, 18, 51-73.

Gupta, K., \& Maksy, M. (2014). Factors associated with student performance in an investments course: An empirical study. Journal of Finance and Accountancy, 16, 86-112.

Heales, J. (2005). Undergraduate performance in accounting and business-based information technology. Accounting \& Finance, 45(3), 395-413.

Henebry, K., \& Diamond, J. (1998). The impact of student and professor gender on grade performance in the managerial finance course. Financial Practice and Education, 8(1), 94-101. 
Hicks, D. W., \& Richardson, F. M. (1984). Predicting early success in intermediate accounting: The influence of entry examination and GPA. Issues in Accounting Education, Spr., 61-67.

Ingram, R. W., \& Peterson, R. J. (1987). An evaluation of AICPA tests for predicting the performance of accounting majors. The Accounting Review, Jan., 215-223.

Jackling, B., \& Anderson, A. (1998). Study mode, general ability and performance in accounting: A research note. Accounting Education: An International Journal, 1, 33-42.

Jenkins, E. K. (1998). The significant role of critical thinking in predicting auditing students' performance. Journal of Education for Business, 5, 274-280.

Johnson, D. L., Joyce, P., \& Sen, S. (2002). An analysis of student effort and performance in the finance principles course. Journal of Applied Finance, 12(2), 67-72.

Kohl, M. Y., \& Kohl, H. C. (1999). The determinants of performance in an accountancy degree course. Accounting Education: An international journal, 1, 13-29.

Lane, A., \& Porch, M. (2002). The impact of background factors on the performance of no specialist undergraduate students on accounting modules - A longitudinal study: A research note. Accounting Education, 1, 109-118.

Lin, Z., \& Songtao, M. (2016). The impact of metacognitive awareness on class performance in financial accounting courses. Academy of Educational Leadership Journal, 20(2), 78-88.

Lipe, M. G. (1989). Further evidence on the performance of female versus male accounting students. Issues in Accounting Education, 1, 144-152.

Lynn, S., \& Robinson-Backmon, I. (2005). An investigation of an upper-division undergraduate accounting course and the factors that influence learning outcomes. Journal of College Teaching \& Learning, 13, 133-140.

Maksy, M. (2012). Motivation and distraction factors associated with student performance in intermediate accounting: An empirical investigation. Journal of Accounting and Finance, 12(3), $188-208$.

Maksy, M. (2014). Factors associated with student performance in intermediate accounting: A comparative study at commuter and residential schools. Journal of Applied Business and Economics, 16(5), 86-104.

Maksy, M. (2017). Factors associated with student performance in advanced accounting: An empirical study at a commuter university. Journal of Applied Business and Economics, 19(9), 42-59.

Maksy, M., \& Rezvanian, R. (2017). Factors associated with student performance in introductory finance: An empirical study at a public university. Journal of International Business Education, 12, $127-$ 154.

Maksy, M., \& Rodriguez, C. (2017). Motivation and distraction factors associated with student performance in auditing: An empirical study at a residential university. Journal of Accounting and Finance, 17(7), 174-193.

Maksy, M., \& Wagaman, D. (2012). Factors associated with student performance in auditing: A comparative study in commuter and residential schools. Journal of Accounting and Finance, $12(2), 120-141$.

Maksy, M., \& Wagaman, D. (2013). Factors associated with student performance in the undergraduate senior seminar in accounting: A comparative study in commuter and residential schools. Journal of Applied Business and Economics, 14(4), 101-119.

Maksy, M., \& Wagaman, D. (2015). Factors associated with student performance in advanced accounting: A comparative study at commuter and residential schools. Journal of Accounting and Finance, 15(1), 72-94.

Maksy, M., \& Yoon, M. (2019). Factors associated with student performance in Cost Accounting II: An empirical study at a US commuter public university. Journal of Applied Business and Economics, 21(1), 71-88.

Maksy, M., \& Zheng, L. (2008). Factors associated with student performance in advanced accounting and auditing: An empirical study in a public university. Accounting Research Journal, 21, 16-32. 
Marks, B. R. (1998). An examination of the effectiveness of a computerized learning aid in the introductory graduate finance course. Financial Practice and Education, 8, 127-132.

Mutchler, J. E., Turner, T. H., \& Williams, D.D. (1987). The performance of female versus male accounting students. Issues in Accounting Education, 1, 103-111.

Nofsinger, J., \& Petry, G. (1999). Student study behavior and performance in principles of finance. Journal of Financial Education, Spr., 33-41.

Paisey, C., \& Paisey, N. (2004). Student attendance in an accounting module - Reasons for nonattendance and the effect on academic performance in a Scottish university. Accounting Education: An International Journal, 13, 39-53.

Pascarella, E., \& Terenzini, P. (1991). How College Affects Students: Findings and Insights from Twenty Years of Research. San Francisco, CA. Jossey-Bass Publisher.

Paulsen, M. B., \& Gentry, J. A. (1995). Motivation, learning strategies, and academic performance: A study of the college finance classroom. Financial Practice and Education, 5(1), 78-89.

Pavione, C. N., Avelino, B. C., \& de Souza Francisco, J. R. (2016). Factors that influence the teachinglearning process from the perspective of accountancy students: Analysis at a higher education institution in Minas Gerais. Revista de Educação e Pesquisa em Contabilidade, 10(2), 192-215.

Poh-Sun, S., \& Suay-Peng, W. (2016). Using a mobile gaming app to enhance accounting education. Journal of Education for Business, 91(8), 434-439.

Rich, S. P. (2006). Student performance: Does effort matter? Journal of Applied Finance, 16(2), 120-133.

Riley, J., \& Ward, K. (2017). Active learning, cooperative active learning, and passive learning methods in an accounting information systems course. Issues in Accounting Education, 32(2), 1-16.

Rohde, F. H., \& Kavanagh, M. (1996). Performance in first year university accounting: Quantifying the advantage of secondary school accounting. Accounting and Finance, 2, 275-285.

Schleifer, L., \& Dull, R. (2009). Metacognition and performance in the accounting classroom. Issues in Accounting Education, 24, 339-367.

Schroeder, N. W. (1986). Previous accounting education and college-level accounting examination performance. Issues in Accounting Education, 1, 37-47.

Schrouder, S. M., \& Rhodd, R. G. (2013). Non-intellectual variables as factors in determining academic success - Are older students likely to be more successful? International Journal of Education and Research, 1(6), 1-12.

Sen, S., Joyce, P., Farrell, K., \& Toutant, J. (1997). Performance in principles of finance courses by students with different specializations. Financial Practice and Education, 7(2), 66-73.

Seow, P. S., Pan, G., \& Tay, J. (2014). Revisiting the determinants of students' performance in an undergraduate accountancy degree program in Singapore. Global Perspectives on Accounting Education, 11, 1-23.

Tan, K. \& Choo, F. (1990). A note on the academic performance of deep-elaborative versus shallowreiterative information processing students. Accounting \& Finance, 15, 549-569.

Tepper, R. J. \& Yourstone, S. A. (2018). Beyond ACT \& GPA: self-efficacy as a non-cognitive predictor of academic success. International Journal of Accounting \& Information Management, 26(1), 171-186.

Tessema, M. T., Ready, K. J., \& Astani, M. A. (2014). Does part-time job affect college students' satisfaction and academic performance (GPA)?: The case of a mid-sized public university. International Journal of Business Administration, 5(2), 50-59.

Tickell, G., \& Smyrnios, K (2005). Predictors of tertiary accounting students' academic performance: A comparison of year 12-to-university students with TAFE-to-University Students. Journal of Higher Education Policy and Management, 27, 239-259.

Tho, L. M. (1994). Some determinants of student performance in the University of Malaya introductory accounting course. Accounting Education: An International Journal, 4, 331-340.

Trout, B. (2018). The effect of class session length on student performance, homework, and instructor evaluations in an introductory accounting course. Journal of Education for Business, 93:1, 16-22. 
Tyson, T. (1989). Grade performance in introductory accounting courses: Why female students outperform males. Issues in Accounting Education, 1, 153-160.

Van Ness, B. F., Van Ness, R. A., \& Adkins, R. L. (2000). Student performance in principles of finance: Difference between traditional and Internet settings. Financial Practice and Education, 10(2), $160-166$.

Wooten, T. (1998). Factors influencing student learning in introductory accounting classes: A comparison of traditional and nontraditional students. Issues in Accounting Education, 13, 357-373.

Wynn-Williams, K., Beatson, N., \& Anderson, C. (2016). The impact of unstructured case studies on surface learners: A study of second-year accounting students. Accounting Education, 25(3), 272286. 


\section{APPENDIX A: TABLES}

TABLE 1

DESCRIPTIVE STATISTICS OF THE STUDY VARIABLES

\begin{tabular}{|c|c|c|c|c|c|}
\hline & $\mathbf{N}$ & Minimum & Maximum & Mean & $\begin{array}{c}\text { Std. } \\
\text { Deviation }\end{array}$ \\
\hline Grade $^{1}$ & 129 & 1 & $\overline{4}$ & 3.65 & .608 \\
\hline Points (in \%) & 129 & 64 & 100 & 89.39 & 6.417 \\
\hline Intended Grade ${ }^{2}$ & 129 & 3 & 4 & 3.93 & .256 \\
\hline IT/IS Skill Level $^{3}$ & 129 & 1 & 3 & 1.65 & .595 \\
\hline Communication Skill Level $^{4}$ & 129 & 2 & 4 & 2.98 & .750 \\
\hline Work Hours & 129 & 0 & 84 & 36.09 & 15.565 \\
\hline Work Type $^{5}$ & 129 & 0 & 3 & 1.31 & .758 \\
\hline Course Load & 129 & 1 & 4 & 2.22 & .831 \\
\hline COBM 401 Grade $^{1}$ & 129 & 2 & 4 & 3.53 & .546 \\
\hline Overall GPA $^{1}$ & 129 & 2.50 & 4.00 & 3.57 & .361 \\
\hline Undergraduate Major ${ }^{6}$ & 129 & 1 & 6 & 3.24 & 2.030 \\
\hline $\mathrm{Age}^{7}$ & 129 & 1 & 3 & 2.25 & .707 \\
\hline Gender $^{8}$ & 129 & 1 & 2 & 1.53 & .501 \\
\hline
\end{tabular}

$\mathrm{A}=4.00 ; \mathrm{B}=3.00 ; \mathrm{C}=2.00 ; \mathrm{D}=1.00$.

${ }^{2} \mathrm{~A}=4.00 ;$ At least $\mathrm{B}=3.00 ; \mathrm{C}$ is fine with $\mathrm{me}=2.00$

${ }^{3}$ Beginner $=1 ;$ Intermediate $=2 ;$ Expert $=3$

${ }^{4}$ Poor $=1$; Average $=2$; Good $=3$; Very Good $=4$

${ }^{5} \mathrm{No}=0$; Business-Related (but not accounting) $=1$; Accounting $=2$; IT Related $=3$

${ }^{6}$ Other Non-business major $=1$; Business Administration $=2$; Marketing $=3$; Management $=4$; Finance $=5 ;$ Accounting $=$ 6

${ }^{7} 20-25$ years $=1 ; 26-30$ years $=2 ;$ Over $30=3$

${ }^{8}$ Female $=1 ;$ Male $=2$

TABLE 2

ONE-WAY ANALYSIS OF VARIANCE (All numbers are for Between Groups Only)

\begin{tabular}{|l|r|r|r|r|l|}
\hline \multicolumn{2}{|c|}{} & \multicolumn{4}{c|}{ Dependent Variables } \\
\hline \multicolumn{1}{|c|}{$\begin{array}{c}\text { Independent } \\
\text { Variables }\end{array}$} & DF & F Value & Sig. & F Value & Sig. \\
\hline Intended Grade & $1 / 128$ & 31.402 & $0.000^{* * *}$ & 32.214 & $0.000^{* * *}$ \\
\hline IT/IS Skill & $2 / 128$ & 9.342 & $0.001^{* * *}$ & 9.656 & $0.000^{* * *}$ \\
\hline Comm. Skill & $2 / 128$ & 47.376 & $0.013^{* *}$ & 48.073 & $0.002^{* * *}$ \\
\hline Work Hours & $18 / 128$ & 1.012 & $0.452^{*}$ & 0.748 & 0.755 \\
\hline Work Type & $3 / 128$ & 2.305 & $0.080^{*}$ & 2.356 & $0.075^{*}$ \\
\hline Course Load & $3 / 128$ & 2.281 & $0.083^{*}$ & 1.722 & 0.166 \\
\hline COBM 401 Grade & $2 / 128$ & 13.834 & $0.000^{* * *}$ & 19.337 & $0.000^{* * *}$ \\
\hline Overall GPA & $38 / 128$ & 2.078 & $0.002^{* * *}$ & 2.436 & $0.000^{* * *}$ \\
\hline UG Major & $5 / 128$ & 2.177 & $0.061^{*}$ & 3.325 & $0.007^{* * *}$ \\
\hline Age & $2 / 128$ & 3.272 & $0.041^{* *}$ & 2.835 & $0.062^{*}$ \\
\hline Gender & $1 / 128$ & 1.401 & 0.239 & 1.699 & 0.195 \\
\hline
\end{tabular}

* Significant at $10 \%$ level of significance using two tails test

** Significant at 5\% level of significance using two tails test

$* * * \quad$ Significant at $1 \%$ level of significance using two tails test 

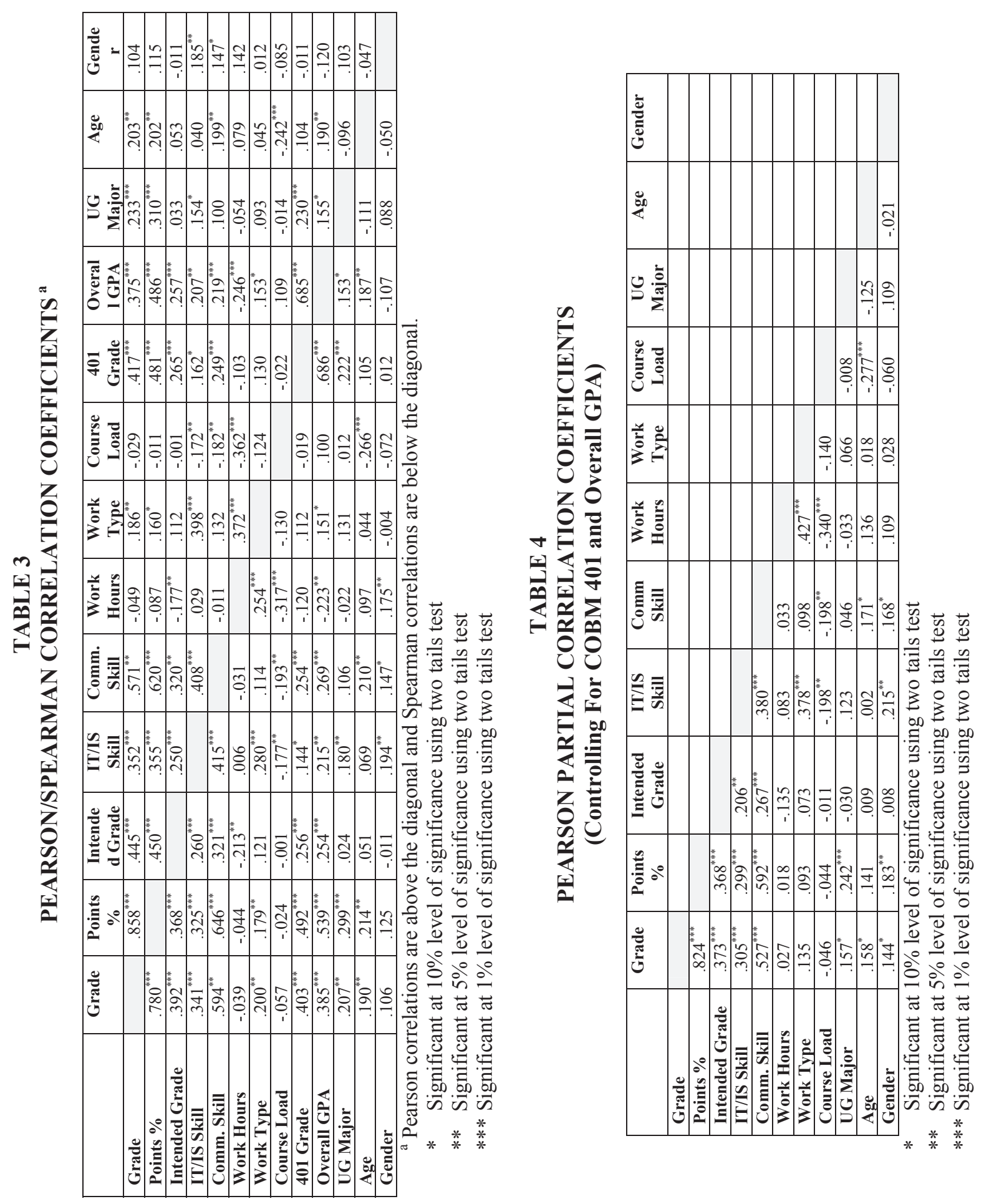

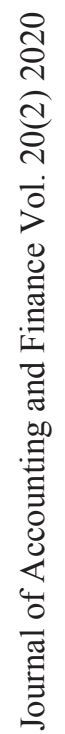


TABLE 5

REGRESSION ANALYSIS

(All numbers are for 129 Observations)

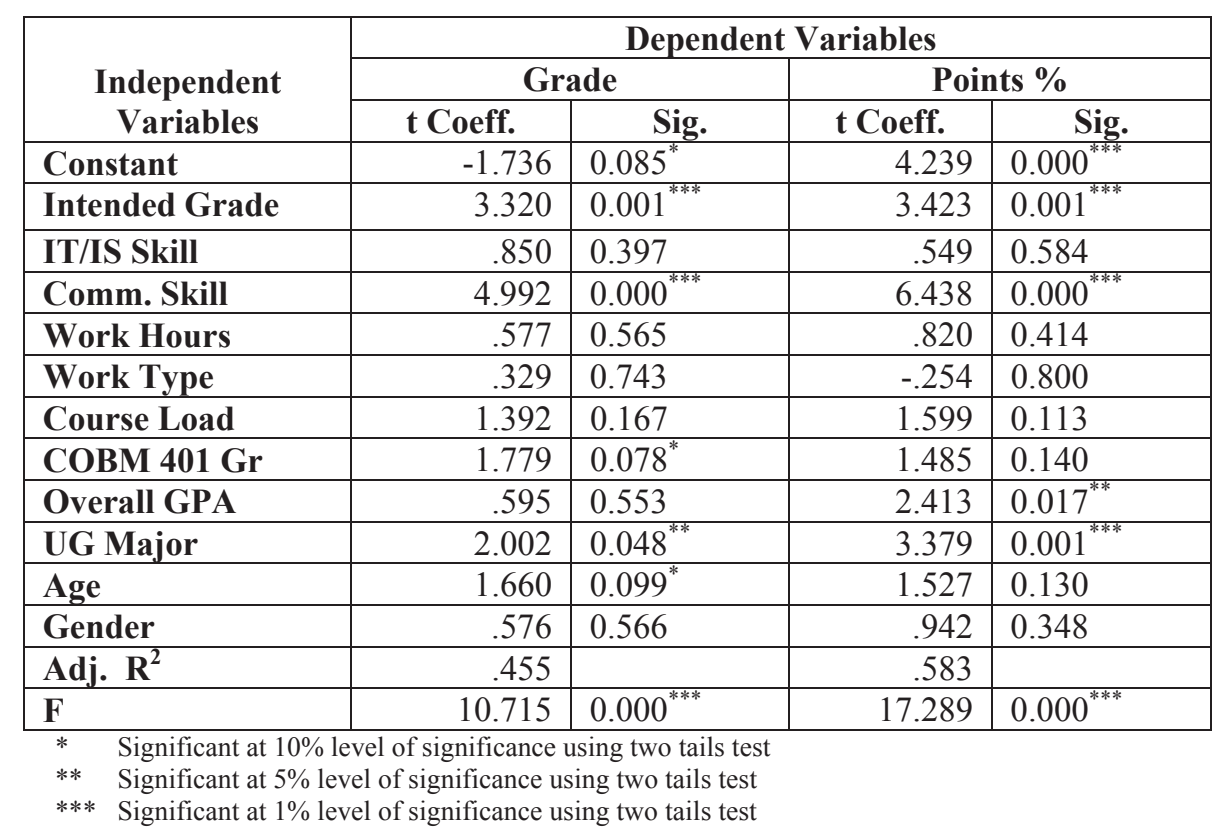

TABLE 6

PARTIAL CORRELATION COEFFICIENTS OF SELECTED FACTORS WITH STUDENT PERFORMANCE

Panel A:

\begin{tabular}{|l|l|l|l|l|}
\hline Dependent Variable & \multicolumn{2}{|l|}{ Grade } & \multicolumn{2}{l|}{ Points \% } \\
\hline Distracting Factor & Coef. & Sig. & Coef. & Sig. \\
\hline Work Hours & -.141 & .115 & -.166 & $.061^{*}$ \\
\hline Work Type & .221 & $.013^{* *}$ & .208 & $.019^{* *}$ \\
\hline Course Load & -.055 & .542 & -.049 & .585 \\
\hline
\end{tabular}

Panel B:

\begin{tabular}{|l|l|l|l|l|}
\hline Dependent Variable & \multicolumn{2}{|l|}{ Grade } & \multicolumn{2}{l|}{ Points \% } \\
\hline Distracting Factor & Coef. & Sig. & Coef. & Sig. \\
\hline Work Hours & -.045 & .615 & -.036 & .693 \\
\hline Work Type & .137 & .126 & .095 & .293 \\
\hline Course Load & -.041 & .653 & -.041 & .650 \\
\hline
\end{tabular}

Panel A: While controlling for other two distracting factors.

Panel B: While controlling for other two distracting factors and prior actual ability factors (COBM 401 Grade and Overall GPA)

* Significant at $10 \%$ level of significance using two tails test

** Significant at $5 \%$ level of significance using two tails test

*** Significant at $1 \%$ level of significance using two tails test 
TABLE 7

GRADE * WORK TYPE CROSS TABULATION

\begin{tabular}{|c|c|c|c|c|c|}
\hline ( & \multicolumn{4}{|c|}{ Work Type } & \\
\hline Grades & $\begin{array}{l}\text { I do not } \\
\text { work }\end{array}$ & $\begin{array}{l}\text { Business related } \\
\text { (not accounting) }\end{array}$ & $\begin{array}{l}\text { Accounting } \\
\text { related }\end{array}$ & IT/IS related & Total \\
\hline D & 0 & 1 & 0 & 0 & 1 \\
\hline C & 0 & 5 & 1 & 0 & 6 \\
\hline B & 4 & 21 & 5 & 0 & 30 \\
\hline $\mathbf{A}$ & 8 & 49 & 24 & 11 & 92 \\
\hline Total & 12 & 76 & 30 & 11 & 129 \\
\hline
\end{tabular}

TABLE 8

GRADE * AGE CROSS TABULATION

\begin{tabular}{|c|c|c|c|c|}
\hline 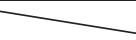 & \multicolumn{3}{|c|}{ Age } & \\
\hline Grades & $20-25$ & $26-30$ & Over 30 & Total \\
\hline D & 1 & 0 & 0 & 1 \\
\hline $\mathrm{C}$ & 1 & 3 & 2 & 6 \\
\hline B & 8 & 13 & 9 & 30 \\
\hline $\mathbf{A}$ & 10 & 41 & 41 & 92 \\
\hline Total & 20 & 57 & 52 & 129 \\
\hline
\end{tabular}

TABLE 9

GRADE * GENDER CROSS TABULATION

\begin{tabular}{|c|r|r|r|}
\hline & \multicolumn{2}{|c|}{ Gender } & \\
\hline Grades & Male & \multicolumn{1}{|c|}{ Female } & \multicolumn{1}{c|}{ Total } \\
\hline D & 0 & 1 & 1 \\
\hline C & 5 & 1 & 6 \\
\hline B & 15 & 15 & 30 \\
\hline A & 40 & 52 & 92 \\
\hline Total & 60 & 69 & 129 \\
\hline
\end{tabular}

TABLE 10

GRADE * UNDERGRADUATE MAJOR CROSS TABULATION

\begin{tabular}{|c|c|c|c|c|c|c|c|}
\hline & \multicolumn{6}{|c|}{ Undergraduate Major } & \\
\hline Grades & $\begin{array}{c}\text { Non- } \\
\text { business }\end{array}$ & $\begin{array}{l}\text { Business } \\
\text { Admin. }\end{array}$ & Marketing & Management & Finance & Accounting & Total \\
\hline D & $(2 \%)$ & $(0 \%)$ & $(0 \%)$ & $(0 \%)$ & $(0 \%)$ & $0 \quad(0 \%)$ & $(1 \%)$ \\
\hline $\mathbf{C}$ & $(9 \%)$ & $(8 \%)$ & $1 \quad(10 \%)$ & $(0 \%)$ & $(0 \%)$ & $0 \quad(0 \%)$ & $(5 \%)$ \\
\hline B & $11(24 \%)$ & $2 \quad(17 \%)$ & $4 \quad(40 \%)$ & $7(47 \%)$ & $3(17 \%)$ & $3(11 \%)$ & $30(23 \%)$ \\
\hline $\mathbf{A}$ & $30(65 \%)$ & $9 \quad(75 \%)$ & $5 \quad(50 \%)$ & $8(53 \%)$ & $15(83 \%)$ & $25(89 \%)$ & $92(71 \%)$ \\
\hline Total & $46(100 \%)$ & $12(100 \%)$ & $10(100 \%)$ & $15(100 \%)$ & $18(100 \%)$ & $28(100 \%)$ & $129(100 \%)$ \\
\hline
\end{tabular}

